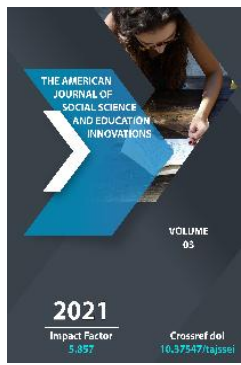

Journal Website: http://theamericanjour nals.com/index.php/taj ssei

Copyright: Original content from this work may be used under the terms of the creative commons attributes

\title{
Computer Graphics As A Means Of Forming Students' Professional Competencies
}

\author{
K.M. Gulyamov
}

Associate Professor, Candidate Of Pedagogical Sciences, National Institute Of Art And Design Named After Kamoliddin Behzod, Tashkent, Uzbekistan

\section{H.N.Arziqulov}

Teacher Of The Department "Methods Of Teaching Computer Science", Navoi State Pedagogical Institute, Navoi, Uzbekistan

\section{ABSTRACT}

The article discusses the formation of professional competencies of students through computer graphics. It also describes the main goals and objectives of teaching computer graphics, the methodological basis of image creation, processing using the basics of software and hardware, engineering graphics and animation.

\section{KEYWORDS}

Computer graphics, computer science, image, animation, methodical, competence, competence in the field of computer graphics, graphic editor.

\section{INTRODUCTION}

The field of informatics related to computer graphics encompasses all types and forms of representation of images by human perception. Computer graphics is used not only in the computer world, but also in the following areas of human activity: scientific research (imagining the structure and vector fields of matter), medicine (computer tomography), design experiments, and more. Computer graphics and animation are a necessary tool in such areas as film, advertising, art, architectural presentations, the creation of logos and images, imitation of shapes, as well as in the creation of computer games and educational programs [2].New directions in the application of computer graphics are constantly being explored, and accordingly, it is expedient to develop pedagogical and methodological approaches in the training of future professionals in this field. This problem is of particular importance in connection with the widespread use of 
information and computer graphics in public life. The need for widespread use of graphics applications has grown significantly, especially due to the development of the global Internet, primarily due to the World Wide Web service, which connects millions of personal "home pages" to a single "spider web". It is hard to imagine any designed web page (website) without computer graphics, pictures and animation. Especially in the current highly competitive process, the fact that a website (website) stands out and attracts public attention requires a special approach.

Changes in social order requirements by society require a qualitatively competent approach to teaching computer graphics. Teaching computer graphics is an important component of modern education, which can be recognized as an independent scientific direction in the development of information and communication technologies.

\section{MATERIALS AND METHODS}

The fact that computer graphics have many meanings, unusual and symbolic meanings, the hiding of certain meanings behind the allegorical form has didactic significance. The use of graphics in educational computer systems not only allows to increase the speed of information and its level of understanding but also contributes to the development of figurative thinking.

The colour of the graphic images stimulates the imagination. Its influence on thoughts and feelings has educational and psychological significance. The tonality and saturation of colours can have a profound effect on the human psyche. Graphics, like other art forms based on the principles of harmony, can activate a person, relieve stress, and consciously stimulate the mind to creative activity [2].
The following scientific and methodological issues determine the urgency of this problem:

- Review of methodological issues of teaching computer graphics to university students;

- Development, substantiation and implementation of components of the methodology of teaching computer graphics [6];

- Identification of favourable pedagogical conditions for effective teaching of university students in the field of computer graphics;

- Substantiation and development of educational and methodological support, training manuals and guidelines for the study of computer graphics, aimed at training competitive professionals for the modern labour market.

The need to consider the methodological issues of teaching computer graphics to university students is due to the lack of clearly developed methods of computer graphics that are not related to architecture, construction and art. Also, due to the lack of methodology for teaching computer graphics in the field of public relations and advertising, it is necessary to develop teaching aids, manuals and guidelines for the study of this topic. In teaching computer graphics, it is desirable to combine education and upbringing, creative activity, the development of students' ability to comprehend and comprehend works of art in conjunction with practical work. The educational standards being developed today, a distinctive feature of the qualification requirements, is a new, competent approach to the formation and evaluation of educational content based on the principle of the practical application of theoretical knowledge. 
The ability to apply this knowledge in practice, to define tasks and solve them independently, to take responsibility for solving problems, forms the basis of the concept of "competence". To date, a certain classification of competencies has been formed, i.e. the range of competencies required for current students. The concept of "competence" refers to the set of laws, principles, requirements, rules, duties, duties and responsibilities that a professional needs. Competence is the ability to demonstrate the norms of competence in the practice of work on the basis of creativity, based on the requirements of society, related to the practical activities of the individual.

The concept of competence has a description of competence-individuality if it has in common with the individual. The main criterion of competence is determined by the results of effective work and training of competent personnel. Although the concepts of 'competence' and 'competence' are content-oriented, they differ in essence, albeit partially. "Competence" refers to the level of demonstration of competency requirements through knowledge, skills and competencies through experience. "Competence" is a sociolinguistic activity based on human knowledge, intellectual and personal experience [1].

Professional competence is understood as an integral characteristic that determines the ability of a specialist to solve professional problems and tasks that arise in real situations of professional activity, using knowledge, professional and life experience, values and inclinations [4].

Based on the definition of competence, it should be acknowledged that there is no upper limit to its development. Also, a person has the opportunity to increase his competence almost indefinitely, limiting the level of his competence only to personal characteristics. An important component of the competence of information and communication technologies is the competence in the field of computer graphics. Basic competence in the field of computer graphics is formed based on general theoretical knowledge and basic tools of graphic editors. The competence of a future computer science teacher in the field of computer graphics is understood not only as knowledge, skills and abilities in the use of computer graphics, but also the ability to move in the modern information flow, graphic training. The competence of a future computer science teacher in the field of computer graphics can be divided into three interrelated components:

- knowledge of the content of competence in the field of computer graphics (cognitive aspect);

- Competence in the field of computer graphics in various standard and nonstandard situations (behavioural aspects);

- Willingness to demonstrate competence in the field of computer graphics (motivational).

Computer graphics has a practical character as a field of scientific research [3]. The main methodological problem of teaching computer graphics is the lack of textbooks for students. In particular, many translated publications that have emerged on computer graphics in recent years can only be used as an annotated dictionary. The textbooks on the formation of basic competencies of future teachers in computer graphics should contain a clear methodological component. It is also important to involve students in the methodological techniques used in the study of computer graphics in the process of getting acquainted with some graphic editors. 
In addition, when monitoring students 'knowledge of computer graphics, offering students to create their learning materials based on the learned graphic editors gives good results. However, despite the students 'interest in computer graphics, many of them are not ready to accept complex and bulky materials during practical work. Working with computer graphics is primarily based on creative thinking and hard work. Faced with such a problem, many students who are not accustomed to overcoming difficulties lose their initial interest in computer graphics [5].

Therefore, they should always be encouraged with a possible outcome. For this purpose, the organization of interactive lessons is of particular importance. As a result, members of the creative team not only develop their creative abilities in the artistic environment but also acquire teamwork skills. In the educational process, students also create projects that help to provide methodological lessons from other subjects $[7,8]$.

Thus, the use of computer graphics, on the one hand, allows students to develop their creative abilities, on the other hand, leads them to reveal the hidden message contained in any visual message. Computer graphics, combined with multimedia tools and high artistic information technologies, allows creating a special graphic information environment for students' creative activities. Given the features discussed above, the study of computer graphics is important.

In particular, computer graphics is a unique tool for developing students' personal qualities such as spatial perception, logical and figurative thinking, sense of colour, creative imagination, the integrity of perception, attention, memory, precision at work. At the same time, the study of computer graphics shapes the ability to transform a visual image into a verbal form, helping to express oneself creatively. It should be noted that computer graphics is an important tool for modelling and demonstrating laws based on artisticgraphic creativity. At the same time, it promotes career-oriented education in terms of the nature of technology, the richness of colour effects, methods of visual representation of objects, computer graphics.

In recent years, students of 5110700 "Methods of teaching computer science" in higher education institutions are taught "Computer Graphics", 5110100 - "Mathematics and Informatics" and "Computer Graphics and Web Design". The main purpose of the subject "Computer Graphics" is to form an understanding of the theory and practice of image creation, processing using the basics of computer technology, engineering graphics and animation. It is also important to equip students with the basic tools and practical methods of working with professional graphic editors, as well as to develop and deepen the general understanding of computer graphics, graphic editors. The main objectives of the course "Computer Graphics" are:

- Formation of concepts about the theoretical foundations of computer graphics;

- To get acquainted with the basic principles and methods of operation of computer graphics algorithms;

- Study of popular graphics programs and publishing systems;

- Have the skills to prepare images for publication, including in electronic form;

- Mastering the basics of computer design;

- To get acquainted with different areas of application of computer graphics methods and tools in modern society.

- Students studying computer graphics should know the following: 
- Theoretical and mathematical bases of computer graphics;

- Basic tools of computer graphics;

- The specific features of different types of computer images and must perform the following:

- Decide whether it is appropriate to use some graphics editors in accordance with the visualization tasks;

- Make independent decisions about the use of certain tools of graphic editors;

- Competent use of various tools of graphic editors;

- Independently identify and solve problems with the visualization of graphic images.

\section{CONCLUSION}

As a result of studying computer graphics, students have increased creative interest in the subject of "Computer Graphics", increased activity in learning new material, a broadened worldview in the field of computer technology, developed imagination and skills of working with graphic editors. In conclusion, such a great interest in the science of computer graphics requires a special approach and serious attention from us, especially given the rapid development of computer graphics as a field of modern scientific research and promising information and communication technologies.

\section{REFERENCES}

1. Gulyamov K.M. (2020). Competence yondashuv asosida blazhak amaliy sanat kituvchilarini kasby faoliyatga tayyerlash tizimini takamillashtirish. Monograph. T .: To'ytepa Print. 156 b.

2. Kodzhaspirova G.M., Petrov K.V. (2005). Technical teaching aids and methods of their use: textbook. manual for students of higher. study. institutions. 2nd ed., Rev. and add. Moscow: Ed. centre "Academy".

3. Computer graphics: textbook $(+\mathrm{CD})$ / M. N. Petrov, V. P. Molochkov. SPb.: Peter, 2010.

4. Kuznetsov A.A., Henner K.K., Imakaev V.R. et al. (2010). Information and communication competence of a modern teacher. Computer science and education. No. 4.

5. Robert I.V., Polyakov V.A. (2004). The main directions of scientific research in the field of informatization of vocational education. Moscow: Education and Informatics Publishing House.

6. Chernyakova T.V. (2010). Methods of teaching computer graphics for university students: dis. ... Cand. ped. sciences. Yekaterinburg.

7. Madaminov, J. Z. (2020). Methods of developing students' design competencies in the discipline "engineering and computer graphics". Academicia: An International Multidisciplinary Research Journal, 10(5), 66-71.

8. Kholmurzaev, A. A., Alijonov, O. I., \& Madaminov, J. Z. (2020). Effective tools and solutions for teaching "Drawing-geometry and engineering graphics". Academicia: An International Multidisciplinary Research Journal, 10(5), 58-61. 